\title{
The Problem With the nORMative Content OF SeCtion 24 OF THE CONSTITUTION OF SOUTH AFRICA
}

WORDS: 10,191

ABSTRACT: The article critically examines the South African Constitutional Court (ZACC) case law and doctrine on section 24 (right to an environment) of the Constitution of South Africa. It argues that the right has been left normatively impoverished, and especially the interaction and relationship with the cornerstone statute, the National Environmental Management Act (NEMA) remains unclear. This issue centres specifically around three core issues. First, it has not been settled whether section 24 encompasses an individual right and an additional positive obligation, or constitutes a composite right. Second, the individual right contained in section 24 requires further definition and clarification. Key terms have not been given distinctive constitutional contours, and it remains uncertain to what extent legislative instruments such as NEMA are legitimately filling these gaps. Finally, it is unclear how the principle of constitutional subsidiarity applies to section 24 of the Constitution. Even assuming that the principle applies in essentially the same way as to other constitutional provisions, one cannot reasonably determine whether ordinary legislation reflects and gives effect to a constitutional right, if one has no clear notion of the latter's content.

\section{A. INTRODUCTION}

This paper is based on an analysis of the environmental case law of the Constitutional Court of South Africa under section 24 of the Constitution. The doctrinal position and normative content of the right has not received much attention in the case law of the ZACC and this has led to considerable uncertainty over its primacy and interaction with a cornerstone piece of ordinary legislation, the National Environmental Management Act (NEMA). As a matter of constitutional theory, the hierarchy of norms enshrined in section 2 of the Constitution is clear: the Constitution is the supreme law of South Africa and should therefore prevail over any provisions provided by ordinary legislation. Such legislation, regardless of how comprehensively it is drafted and how instrumental it is in the adjudication and practice of environmental cases remains in a secondary role. Provided that the Constitution is well drafted, reasonably clear, and faithfully applied, it should form the basis for any determination on the 
status, role and scope of ordinary legislation, and particularly how it fits into the broader legal system, a hierarchy of norms, and its interaction with other provisions.

However, the constitutional theory and the reality are rarely that frictionless and clear: constitutional provisions and ordinary legislation inevitably interact, expanding and limiting each other's scope of application. This of course occurs well before they are ever applied in the context of a specific case in a court, which brings its own complexities and at times holds unintended consequences. In order to ensure the primary application of legislation wherever it is designed to give effect to a constitutional provision, South African Constitutional Law has developed the principle of constitutional subsidiarity. ${ }^{1}$ The principles states that ' $(\ldots)$ where legislation has been enacted to give effect to a right, a litigant should rely on that legislation in order to give effect to the right or alternatively challenge the legislation as being inconsistent with the Constitution. ${ }^{2}$ However, there is a danger when doctrine and conceptualization of the normative claims of constitutional provisions become impoverished, and ordinary legislation takes on a dominant role in the adjudication of constitutional matters.

If a Constitution is to live up to its primacy over ordinary legislation, especially on questions with fundamental constitutional implications, it seems that we require a reasonably clear idea of what the constitutional provision requires, what normative claims it makes distinct from ordinary legislation. The normative content of constitutional provisions must be determined independently of even the most comprehensive instruments of ordinary legislation for reasons that chiefly revolve around the status and function of the constitution as a standard of review for administrative action and legislation. Otherwise we risk defining the scope of protection afforded under a constitutional right exclusively by reference to our interpretation of ordinary legislation, thus rendering, paradoxically, ordinary legislation the precursor to the constitutional provision: it becomes exceedingly difficult, perhaps even practically impossible, to challenge the constitutionality of ordinary legislation on the basis of a normatively and doctrinally empty constitutional right.

With section 24, the Constitution of South Africa contains a provision where I believe these concerns are currently acute, and where an infusion of fresh doctrinal engagement is required in order to mitigate the risk of dominance of ordinary legislation on core constitutional

\footnotetext{
${ }^{1}$ The general existence of this principle is settled case law, see Member of the Executive Council for Development Planning and Local Government, Gauteng v Democratic Party and Others [1998] ZACC 9; 1998 (4) SA 1157 at [62]; My Vote Counts NPC v Speaker of the National Assembly and Others [2015] ZACC 31 at [54]; on the principle in general, see Lourens Du Plessis, 'Subsidiarity: What's in the Name for Constitutional Interpretation and Adjudication' (2006) 17 Stellenbosch L Rev 207.

${ }^{2}$ Mazibuko and Others $v$ City of Johannesburg and Others [2009] ZACC 28 at [73].
} 
questions. There are a number of unresolved doctrinal questions that have been insufficiently addressed by the current case law of the ZACC.

First, it is unclear if section 24 encompasses an individual right and an additional positive obligation, namely in the guise of section 24 (a) and (b) respectively, or whether section 24 must be treated holistically, as a composite right. Constitutional Court rulings have been ambiguous on this question, but it is a crucial distinction. If section 24 is not a composite right, then the express instruction to create instruments of ordinary legislation that give effect to the right, and the principle of subsidiarity may well work differently with respect to section 24(a) than with section 24 (b). Alternatively, if section 24 is a composite right then the legislative instruction would apply to both provisions. This would in turn render section 24 more similar to other provisions of the Constitution that are given effect largely through ordinary (quasi constitutional) legislation, such as Promotion of Access to Information Act with respect to section 32 (2) of the Constitution.

Second, the individual right contained in section 24 requires further definition and clarification. Key terms have not been given distinctive constitutional contours, and it remains uncertain to what extent legislative instruments such as NEMA are able to fill these gaps. Even assuming that legislation such as NEMA gives complete effect to the constitutional right, it will at times produce overlaps with other legislative instruments. Therefore the constitutional provisions must have some level of autonomy of meaning in order to coordinate the different provisions of ordinary legislation and apply them in the context of specific cases.

Finally, it is unclear how the principle of constitutional subsidiarity applies to section 24 of the Constitution. The case law has been ambiguous on this question and analogies with other constitutional provisions are difficult to transfer to section 24. Even assuming that the principle applies in essentially the same way as to other constitutional provisions, any practical application necessitates a clear idea of the normative content of section 24 . This is because the application of the principle of subsidiarity requires an assessment of whether ordinary legislation actually gives effect to a constitutional right. However, one cannot reasonably determine whether ordinary legislation reflects and gives effect to a constitutional right, if one has no clear notion of the latter's content. ${ }^{3}$ Currently, there is a gap which is being filled in a constitutionally questionable manner through legislation such as the NEMA.

\footnotetext{
${ }^{3}$ A similar point is made by Anel Du Plessis, 'South Africa's Constitutional Environmental Right (Generously) Interpreted: What is in it for Poverty?' (2011) 27 South African Journal on Human Rights 279, 303.
} 
This paper will elaborate and develop these concerns through an analysis of the ZACC case law on section 24. In an effort to chart a path towards a more considered and nuanced engagement with the constitutional implications of section 24, the paper will draw on doctrinal developments on related constitutional rights and the role of ordinary legislation in giving effect to constitutional rights: particular attention will be paid to the broader constitutional context and the principle of subsidiarity.

\section{B. THE RIGHT TO AN ENVIRONMENT}

Section 24 of the Bill of Rights of the Constitution of South Africa incorporates the principle of environmental protection and sustainable development into the constitutional law of South Africa, and generally recognizes the fundamental importance of the environment. ${ }^{4}$ It is thus a central provision that underpins the environmental governance regime in South Africa. ${ }^{5}$ The provision states:

Everyone has the right

a. to an environment that is not harmful to their health or well-being; and

b. to have the environment protected, for the benefit of present and future generations, through reasonable legislative and other measures that

i. prevent pollution and ecological degradation;

ii. promote conservation; and

iii. secure ecologically sustainable development and use of natural resources while promoting justifiable economic and social development.

Although there is some uncertainty surrounding the question, section 24 is generally thought to contain both a fundamental individual right (paragraph a), as well as a source of positive obligations for the state (paragraph b.). ${ }^{6}$ These constitutional provisions are flanked by a

\footnotetext{
${ }^{4}$ Fuel Retailers Association of SA (Pty) Ltd v Director General, Environmental Management Mpumalanga and others [2007] ZACC 13 at [102].

${ }^{5}$ Louis J Kotzé, 'The judiciary, the environmental right and the quest for sustainability in South Africa: A critical reflection' (2007) 16 Review of European Community \& International Environmental Law 298, 299; Loretta Feris, 'Constitutional environmental rights: An under-utilised resource' (2008) 24 S Afr J on Hum Rts 29, 49; Rachel Wynberg and David Fig, 'Realising Environmental Rights' in M Langford and others (eds), Socio-Economic Rights in South Africa: symbols or substance? (Cambridge University Press 2014), p. 310; Jan Glazewski, Environmental Law in South Africa (Butterworths 2000), p. 78; James R. May and Erin Daly, Global Environmental Constitutionalism (Cambridge University Press 2015), p. 50.

${ }^{6}$ HTF Developers (Pty) Ltd (Pty) Ltd v. Minister of Environmental Affairs and Tourism and Others [2006] ZAGPHC 132 at [17]; Michael Kidd, 'Environment' in I Currie and J de Waal (eds), The Bill of Rights Handbook (6 edn, Juta 2016), p. 518; Loretta Feris, 'Constitutional environmental rights: An under-utilised resource', 36; Jan Glazewski, Environmental Law in South Africa, p. 85.
} 
comprehensive environmental framework statue, the National Environmental Management Act (NEMA), ${ }^{7}$ which can be seen as one of the legislative instruments that seeks to meet the positive obligations of the state set out in paragraph $b$. The case law of the Constitutional Court of South Africa (ZACC) on section 24 is limited, especially with regard to the scope and content of substantive protection the provision offers to individuals: pertinent rulings largely originate from inferior courts and are therefore somewhat less authoritative. Nonetheless, as we will see, they have provided important insights and clarifications to section 24 that may form part of a more comprehensive doctrinal approach in the future.

The term 'environment' is defined in NEMA as the land, the water and the atmosphere of the earth; micro-organisms, plant and animal life; any part or combination of the first two items on this list, and the interrelationships among and between them; and the physical, chemical, aesthetic and cultural properties and conditions of the foregoing that influence human health and well-being. It should be noted, that the ZACC has not pronounced itself on the constitutional understanding of the term 'environment' in section 24. Indeed the state of legal doctrine on section 24 has been the subject of criticism in legal scholarship. Michael Kidd states that 'It would appear that the judges' performance is rather 'chequered' in environmental cases, which suggests that the judiciary needs to become more attuned to environmental law' and Loretta Feris laments that 'when one examines South African jurisprudence, there seems to be a marked dearth in cases where the environmental right has been fully utilised and clearly interpreted. ${ }^{8}$ This may well be explained by any number of reasons ranging from a lack of environmental training and awareness on the part of lawyers, as well as the relatively recent addition of many pieces of environmental legislation. Scholars appear to generally agree that sufficiently more expertise must be cultivated before section 24 can begin to have a significant impact on legal practice and adjudication. ${ }^{9}$

Most cases before the ZACC engaging with section 24 revolve around the interpretation of procedural protections under statutory provisions related to environmental protection. Bengwenyama v. Genorah dealt with the fairness requirement for administrative proceedings in a case on the allocation of prospecting rights, ${ }^{10}$ National Society for the Prevention of Cruelty to Animals decided whether the NSPCA was authorised under the SPCA Act to institute private

\footnotetext{
${ }^{7}$ National Environmental Management Act 107 of 1998, as amended 18 December 2014; Environment Conservation Act 73 of 1989, as amended 18 September 2009.

${ }^{8}$ Michael Kidd, 'Greening the judiciary' (2006) 9 Potchefstroom Electronic Law Journal 1, 1; Loretta Feris,

'Constitutional environmental rights: An under-utilised resource', 38.

${ }^{9}$ Rachel Wynberg and David Fig, 'Realising Environmental Rights', p. 336 et seq.

${ }^{10}$ Bengwenyama (Pty) Ltd and Others v Genorah (Pty) Ltd and Others [2010] ZACC 26.
} 
prosecution against individuals, ${ }^{11}$ and the crux of the case in HTF Developers Pty Limited was whether the observance of a 30-day notice and commentary period was necessary for environmental protection directions made to a specific person or entity under the Environmental Conservation Act. ${ }^{12}$ A similar issue lay at the heart of the more recent the decision in Earthlife Africa. ${ }^{13}$ The applicant NGO challenged the authorisation for the construction of a new coal fired power station on the basis of environmental concerns, particularly a failure to consider the climate change impacts of the project. The basis for this was that section 240(1) NEMA, which requires a climate change impact assessment before authorisation can be granted. ${ }^{14}$ The High Court agreed that the authorisation should not have been granted without such an impact assessment, in part because the authorisation could not be withdrawn entirely once issued and hence subsequent remedies would be fruitless. ${ }^{15}$

Section 24 was also discussed in a case regarding the delineation of provincial and national sphere of competence in zoning law. In Maccsand v. City of Cape Town, the ZACC had to settle the question whether a permit issued under the Mineral and Petroleum Resources Development Act by the competent Minister was sufficient to overcome the lack of a rezoning decision under provincial law. ${ }^{16}$ The ZACC ultimately held that both provincial and national provisions applied jointly, and hence provincial zoning laws applied alongside and were not rendered superfluous through the provisions of the Mineral and Petroleum Resources Development Act. ${ }^{17}$ Thus, in the absence of a rezoning decision by the City of Cape Town the mining operations in the relevant area were illegal.

Apart from these procedurally focused cases, there is a significant, if limited, number of substantive environmental cases that deal with claims either seeking protection from environmental harm or alleging infringements through measures designed to protect the environment. The section will commence by briefly outlining the doctrinal position adopted by the ZACC and lower courts, before critically engaging with the role of ordinary legislation in constitutional law and its relevance for section 24 specifically.

\footnotetext{
${ }^{11}$ National Society for the Prevention of Cruelty to Animals v Minister of Justice and Constitutional Development and others [2016] ZACC 46.

${ }^{12}$ MEC Department of Agriculture, Conservation and Environment and Another $v$ HTF Developers (Pty) Limited [2007] ZACC 25.

${ }^{13}$ Earthlife Africa Johannesburg v Minister of Environmental Affairs and Others [2017] ZAGPPHC 58.

${ }^{14}$ Ibid at [12].

15 Ibid at [114].

${ }^{16}$ Mineral and Petroleum Resources Development Act 28 of 2002, as amended 7 December 2014.

${ }^{17}$ Maccsand (Pty) Ltd $v$ City of Cape Town and Others [2012] ZACC 7, at [51].
} 


\section{Subsection a}

Section 24 (a) states that 'everyone has the right to an environment that is not harmful to their health or well-being'. The ZACC has clarified that section 24 (a) contains an individual a right to a healthy environment, and that it forms the basis for legislation that guarantees the protection of the environment. ${ }^{18}$ Both the terms 'environment' as well as 'health' and 'well-being' are not specified further in the constitution. The High Court suggests that the terminology employed must be interpreted in the sense that 'well-being' overlaps, but goes beyond 'health' to encompass a more holistic sense of the environment: ${ }^{19}$ it can thus be read as incorporating interests of people in the environment that are rooted in intrinsic or aesthetic value, ${ }^{20}$ and has been qualified as 'open-ended and manifestly is incapable of precise definition. ${ }^{21}$ This is also the view expressed by Anél du Plessis who attempts to offer some preliminary definitions of core terminology employed. ${ }^{22}$

Judicial pronouncements on the scope of protection have been less detailed. In a series of rulings, the High Court has opined that section 24 contains a positive obligation of the state to protect individuals from the effects of environmental pollution and degradation. ${ }^{23}$ In the case of Hichange Investments, the applicant sought relief from chemical waste originating from a tanning business carried out by the first respondent on neighbouring property. ${ }^{24}$ The applicant complained inter alia of noxious gases and odour, alleging they constituted a threat to health and well-being within the meaning of section 24 (a). The High Court appeared to accept this as

\footnotetext{
${ }^{18}$ Fuel Retailers Association of SA (Pty) Ltd v Director General, Environmental Management Mpumalanga and others [2007] ZACC 13 at [40]; Loretta Feris, 'Constitutional environmental rights: An under-utilised resource', 39.

${ }^{19}$ HTF Developers (Pty) Ltd (Pty) Ltd v. Minister of Environmental Affairs and Tourism and Others [2006] ZAGPHC 132 at [18]; Michael Kidd, 'Environment', p. 522; Louis J Kotzé and Anél du Plessis, 'Some brief observations on fifteen years of environmental rights jurisprudence in South Africa' (2010) 3 J Ct Innovation 157, 166-167.

${ }^{20}$ Hichange investments (Pty) Ltd v Cape Produce Co (Pty) Ltd t/a Pelts Products and Others [2004] 2 SA 393

(E) [which seemed to endorse this broader reading]; Paola $v$ Jeeva NO and Others [2003] ZASCA 100 [on the aesthetic value of an ocean view]; Louis J Kotzé, 'The judiciary, the environmental right and the quest for sustainability in South Africa: A critical reflection', 300; Jan Glazewski, Environmental Law in South Africa, p. 77.

${ }^{21}$ HTF Developers (Pty) Ltd (Pty) Ltd v. Minister of Environmental Affairs and Tourism and Others [2006] ZAGPHC 132 at [18].

${ }^{22}$ Anel Du Plessis, 'South Africa's Constitutional Environmental Right (Generously) Interpreted: What is in it for Poverty?', 292.

${ }^{23}$ Hichange investments (Pty) Ltd v Cape Produce Co (Pty) Ltd t/a Pelts Products and Others [2004] 2 SA 393 (E), p. 16; Minister of Water Affairs and Forestry v. Stilfontein Gold Mining Company Ltd and Others [2006] ZAGPHC 47 at [16.9]; HTF Developers (Pty) Ltd (Pty) Ltd v. Minister of Environmental Affairs and Tourism and Others [2006] ZAGPHC 132 at [16].

${ }^{24}$ Hichange investments (Pty) Ltd v Cape Produce Co (Pty) Ltd t/a Pelts Products and Others [2004] 2 SA 393 (E).
} 
infringing the applicants well-being. ${ }^{25}$ The key issue was whether the state had discharged its positive obligation, determined by the severity of the pollution, based on scientific evidence. ${ }^{26}$ In determining what constitutes sufficiently severe pollution for the purposes of section 28 NEMA, the High Court referred to section 24 of the Constitution, noting that the broad definition of health and well-being suggested a low threshold. ${ }^{27}$ However, the High Court was ultimately not convinced that the pollution rose to a sufficient level of severity to find a violation. $^{28}$

The case of Harmony Gold was not directly concerned with the protection afforded to individuals under section 24 of the Constitution. ${ }^{29}$ However, it established that private actors could be lawfully required to contribute to the costs of preventing pollution, even where it does not directly originate from their property. The case concerned a government order under section 19(3) of the National Water Act that sought to prevent water pollution by requiring the appellant to contribute towards the costs of on-going pumping operations in a defunct mine. The financial sustainability of the pumping operation had been jeopardised through the bankruptcy of the company that owned the defunct mine, which was connected through historic shafts with other active operations. The pumping operation was hence essential to prevent the flooding and further contamination of water flowing to adjacent mines owned by the applicant. Despite the fact that the mining operations of Harmony Gold would be jeopardised if water pumping did not continue, it challenged the legality of the order.

Section 24 of the Constitution is mentioned only in passing as providing the basis for any interpretation of section 19 of the National Water Act. ${ }^{30}$ However, the Court of Appeal did find that the appellant was lawfully required to contribute to the costs of preventing pollution of ground water, even though it was not formally and directly responsible for the defunct mine. ${ }^{31}$ While this conclusion was ultimately based on the interpretation of the National Water Act, it does point to an important dimension of section 24 (a) of the Constitution. Insofar as the economic activity of companies threatens the pollution of the environment, they may be required to contribute to the costs of averting the threat: notwithstanding whether their activity

\footnotetext{
${ }^{25}$ Ibid, p. 21 .

${ }^{26}$ Ibid, p.16.

${ }^{27}$ Ibid, p.16-17.

${ }^{28}$ Ibid, p.16-17.

${ }^{29}$ Harmony Gold Mining Company Limted v Regional Director Free State Department of Water Affairs and Forestry and Another [2006] ZASCA 66.

${ }^{30}$ Ibid at [17].

${ }^{31}$ Ibid at [35].
} 
is otherwise lawful and whether the threat originates from their property, or arises commutatively form their joined activities with those primary responsible.

More recently, the High Court decision in Stern epitomises the current lack of engagement with section 24 of the Constitution. ${ }^{32}$ Even though the applicants specifically challenged the constitutionality of a decision of the Minister of Mineral Resources creating Regulations for Petroleum Exploration, the High Court does not so much as mention section 24 and instead engages exclusively with ordinary legislation, especially NEMA.

\section{Subsection $b$}

Section 24 (b) is phrased in terms of a positive obligation requiring the state to (i) prevent pollution and ecological degradation, (ii) promote conservation, and (iii) secure ecologically sustainable development and use of natural resources while promoting justifiable economic and social development. As such, it is generally believed to primarily obligate the State. ${ }^{33}$ A recent ruling in the Supreme Court of Appeal also hints at this conclusion, even though it only briefly engages with the provision. ${ }^{34}$ The case concerned the exercise of customary fishing rights by the Hobeni community. The Supreme Court of Appeal found that the customary rights of access to marine resources constituted a defence against unlawful conduct under section 43 of the Marine Living Resources Act. ${ }^{35}$ In passing, the Court commented on the nature of section 24 of the Constitution as mandating 'environmental protection and conservation of the state. ${ }^{36}$

Only one case before the ZACC has dealt with the interpretation of section 24 (b) in any meaningful way, dealing with solely with the concept of sustainable development: Fuel Retailers. ${ }^{37}$ The case involved an application for the construction of a filling station (petrol station), which was granted by local environmental authorities. The permit was opposed by the applicant association, which raised environmental concerns, although Sachs J observed in his dissenting opinion the oddity that an organization representing the interests of fuel retailers championed environmental interests. ${ }^{38}$ The case afforded the ZACC the opportunity to discuss

\footnotetext{
${ }^{32}$ Stern NO and Others $v$ Minister of Mineral Resources [2017] ZAECGHC 109.

${ }^{33}$ Michael Kidd, 'Environment', p. 528; Anel Du Plessis, 'South Africa's Constitutional Environmental Right (Generously) Interpreted: What is in it for Poverty?' 299.

${ }^{34}$ Gongqose and Others v Minister of Agriculture, Forestry and Others, Gongqose and S [2018] ZASCA 87

${ }^{35}$ Ibid at [2].

${ }^{36}$ Ibid at [66].

${ }^{37}$ Fuel Retailers Association of SA (Pty) Ltd v Director General, Environmental Management Mpumalanga and others [2007] ZACC 13.

${ }^{38}$ Ibid, Dissenting Opinion Sachs J at [109].
} 
the nature of environmental protection under section 24 and its relationship with socioeconomic development and sustainable development, holding that:

'Economic and social development is essential to the well-being of human beings. (...) But development cannot subsist upon a deteriorating environmental base. Unlimited development is detrimental to the environment and the destruction of the environment is detrimental to development. Promotion of development requires the protection of the environment. ${ }^{39}$

Indeed, the court held that under section 24 '[s]ustainable development and sustainable use and exploitation of natural resources are at the core of the protection of the environment. ${ }^{40}$ Following an in-depth consideration of the concept of sustainable development in International and domestic law, the ZACC reprimanded the local environmental department for failing to consider the environmental impact of the petrol station after the town planning authorities had made determinations with respect to socio-economic impact. Environmental officials were held under a duty, particularly under section 24 (1) NEMA to conduct their own independent review, instead of delegating this duty to town planning authorities. ${ }^{41}$ The Court dismissed unilateral disengagement, and drew on the Constitution as the final arbiter and guideline in balancing competing considerations of development and environmental protection. ${ }^{42}$ However, this review appeared limited to procedural investigations of the administrative action in question, as opposed to involving a substantial review based on the normative claims of section 24 .

The High Court has expanded on this understanding to include a requirement that legislative measures must be reasonably capable of realizing environmental protection. ${ }^{43}$ From section 24 (b) the High Court derived a duty of the state to take reasonable legislative measures to protect the environment. This decision echoes the procedural based ruling in the landmark ruling on section 26 (Right to adequate housing) of Government of the Republic of South Africa and Others v. Grootboom and Others, where the ZACC held that:

'Legislative measures by themselves are not likely to constitute constitutional compliance. Mere legislation is not enough. The State is obliged to act to achieve the intended results, and the legislative measures will invariably have to be supported by appropriate, well-directed policies and programmes implemented by the Executive. These policies and programs must be reasonable both in their conception and their implementation. ${ }^{44}$

\footnotetext{
${ }^{39}$ Ibid at [44] (footnotes omitted).

${ }^{40}$ Ibid at [45].

${ }^{41}$ Ibid at [92].

${ }^{42}$ Ibid at [93].

${ }^{43}$ BP Southern Africa (Pty) Limited v Mec for Agriculture, Conservation, Environment \& Land Affair [2004] ZAGPHC 18, p. 22; MEC for Agriculture Conservation, Environment and Land Affairs Gauteng v. Sasol Oil (Pty) Ltd and another [2005] ZASCA 76 at [14];

${ }^{44}$ Government of the Republic of South Africa and Others $v$ Grootboom and Others [2000] ZACC 19 at [42].
} 
Crucially, the High Court and the Supreme Court of Appeal have affirmed that economic development could not be the sole determinate factor, as it must be balanced with environmental concerns, and both must be considered jointly, as they are equally important constitutional interests. ${ }^{45}$ However, overall the normative scope and implications of section 24 (b) remain largely unclear on some key questions. ${ }^{46}$ The concerns range from establishing legal definitions for terms like sustainable development to issues surrounding the status and relevance of positive obligations: for instance, whether they are limited to the provisions of 24 (b) or have further implications for section 24 (a) and thus the application of the doctrine of subsidiarity. We will explore the latter issue further below. Primarily, this uncertainty is owed to the limited number of pertinent cases, and the apparent reluctance of the ZACC and lower courts to move beyond a largely procedural based review of administrative action. It is correct that section 24 is supplemented and indirectly discussed in the context of some more specified rights, such as the access to sufficient water and healthcare (section 27), right to life (section 11), equality (section 9) and dignity (section 10). ${ }^{47}$ However, these occasional references and dispersed engagement serves only to highlight the absence of clear constitutional doctrine on section 24. Currently, the doctrine lacks the engagement and cohesion necessary to provide a reasonably clear standard of review for administrative action beyond the general principles of sound administrative practice and procedure, to say nothing of the specific contours necessary for a constitutional review of ordinary legislation. In this sense, section 24(b) mirrors closely the conclusions drawn from the case law on section 24(a). This is a problematic state of affairs that leaves much to be desired for constitutional jurisprudence for reasons that I shall now turn towards.

\section{The role of ordinary legislation}

This prevailing doctrinal uncertainty surrounding section 24 raises the question what role the case law affords to ordinary legislation, and whether it can be drafted to exhaustively state, perhaps even modify the scope of constitutional rights. Should ordinary legislation take on such a pivotal role, this would challenge the idea that section 24 can anchor a comprehensive standard of review for the constitutionality of legislation and regulatory action. Indeed, in a few

\footnotetext{
${ }^{45}$ BP Southern Africa [2004] ZAGPHC 18, p. 22; All the Best Trading CC and Others $v$ S N Nayagar Property Development and Construction CC and Others [2005] ZAGPHC 17, p.4; Sasol Oil [2005] ZASCA 76 at [16]; Eric C. Christiansen, 'Empowerment, Fairness, Integration: South African Answers to the Question of Constitutional Environmental Rights’ (2013) 32 Stan Envtl LJ 215, 257.

${ }^{46}$ James R. May and Erin Daly, Global Environmental Constitutionalism, p. 265.

47 Environmental Law and Local Government in South Africa (A du Plessis ed, Juta 2016).
} 
passages in the case of Fuel Retailers the ZACC appears to suggest such a role for ordinary legislation, effectively delineating the scope of protection available under section 24 :

'Section 24 of the Constitution guarantees to everyone the right to a healthy environment and contemplates that legislation will be enacted for the protection of the environment. ECA and NEMA are legislation which give effect to this provision of the Constitution. The question to be considered in this application is the proper interpretation of the relevant provisions of ECA and NEMA and, in particular, the nature of the obligations imposed by these provisions on the environmental authorities. ${ }^{48}$

'[The principles of NEMA] provide not only the general framework within which environmental management and implementation decisions must be formulated, but they also provide guidelines that should guide state organs in the exercise of their functions that may affect the environment. Perhaps more importantly, these principles provide guidance for the interpretation and implementation not only of NEMA but any other legislation that is concerned with the protection and management of the environment. It is therefore plain that these principles must be observed as they are of considerable importance to the protection and management of the environment. ${ }^{49}$

On this basis, some scholars have suggested that ordinary legislation, to varying degrees, gives effect to the environmental right under section 24(a), both with respect to substance and standing. Loretta Feris endorses such a role of ordinary legislation when she suggests that issues over the vagueness of section 24 have been addressed through legislative action, and that the role of the judiciary is primarily one of enforcement. ${ }^{50}$ This is echoed by Rachel Wynberg and David Fig, who emphasises that most environmentally related substantive and procedural rights have been translated into ordinary statutes. In this way, enabling legislation gives 'effect to the constitutional right to an environmentally sustainable society, as well as sector-specific legislation that can be used to uphold environmental rights. ${ }^{51}$ Eric Christiansen likewise argues that ordinary legislation such as NEMA '(...) informs the protection and enforcement of Section 24 rights in a host of environmental statutes. The Constitution imbues NEMA with authority and NEMA defines and clarifies the appropriate expression of that authority in all other environmental legislation. ${ }^{52}$

\footnotetext{
${ }^{48}$ Fuel Retailers Association of SA (Pty) Ltd v Director General, Environmental Management Mpumalanga and others [2007] ZACC 13 at [40] (footnotes omitted).

${ }^{49}$ Ibid, at [67] (footnotes omitted).

${ }^{50}$ Loretta Feris, 'Constitutional environmental rights: An under-utilised resource', 36-38 and 49; this emphasis on enforcement is also expressed by Michael Kidd, 'Environment', p. 529; and Eric C. Christiansen, 'Empowerment, Fairness, Integration: South African Answers to the Question of Constitutional Environmental Rights', 254.

${ }^{51}$ Rachel Wynberg and David Fig, 'Realising Environmental Rights', p. 316.

${ }^{52}$ Eric C. Christiansen, 'Empowerment, Fairness, Integration: South African Answers to the Question of Constitutional Environmental Rights', 254.
} 
Christiansen thus hints strongly at a special role for the NEMA in defining and delineating the scope of the environmental right contained in section 24 of the Constitution. ${ }^{53}$ According to this view, legislation such as the NEMA, thus arguably takes on the form of quasi constitutional legislation, ${ }^{54}$ which takes precedence over other ordinary legislation that deals with environmental concerns. Michael Kidd also broadly endorses this view, but expands it to cover standing. ${ }^{55}$ Overall, the scholarship seems to suggest at the very least that statutes such as NEMA are the initial port of call for any applicant raising an environmental claim and that it would require extraordinary circumstances to vacate its provisions on substance and standing in favour of the provisions of the Constitution.

This scholarly view is certainly correct as far as it goes: to the extent that the provisions in NEMA are as broad as the constitutional requirements, there is no conflict. NEMA is under these circumstances rightfully invoked in ordinary application of the principle of subsidiarity. However, should the provisions be more restrictive than permissible under the section 24 , then the latter would again take precedence, to the extent that it does not render the more restrictive provision unconstitutional. Crucially, however, the doctrine on section 24 is not currently in a sufficient state of maturity and sophistication to furnish such a standard of review for NEMA. Indeed, legislation is the core and at times the sole point of reference for environmental decisions taken by South African courts, including the ZACC. The courts thus neglect this essential role for constitutional doctrine, which becomes apparent when considering the broader constitutional context.

\section{The broader constitutional context}

The Constitution, as the supreme law of South Africa, ${ }^{56}$ generally prevails over any provision of ordinary legislation. ${ }^{57}$ This certainly applies to direct conflicts between legislative and constitutional provisions, for instance between section 32 (1) NEMA and section 38 of the Constitution which both address legal standing of individuals. An argument to the effect that suggests that section 32 (1) NEMA can limit the standing generally granted under section 38 of the Constitution is untenable in light of the clear wording of the Constitution.

\footnotetext{
53 Ibid, 258.

${ }^{54}$ Ibid, 270.

${ }^{55}$ Michael Kidd, 'Environment', p. 527.

${ }^{56}$ Constitution of the Republic of South Africa, 1996 [No. 108 of 1996] - G17678 (adopted 18 December 1996, in force 4 February 1997), section 2.

${ }^{57}$ Louis J Kotzé, 'The judiciary, the environmental right and the quest for sustainability in South Africa: A critical reflection', 310 .
} 
The more complex case arises where there is no direct conflict, but where ordinary legislation purports to give effect to the substance of a right, or determines the conditions under which it can be invoked. ${ }^{58}$ However, it is not clear that this interpretation is necessarily accepted in the judgments of the ZACC, nor that cases of direct conflict with constitutional provisions are the only ones that ought to cause concern. Indeed, this section argues that even absent direct conflict, a clear notion of the normative claims of section 24 of the Constitution is required to ensure the proper functioning of rights based litigation and constitutional review.

Before turning to that aspect, we shall first examine the scope of the authority offered in support of a more limited role for constitutional rights in environmental litigation as far as NEMA is relevant to a particular case. This position is based on the authority of statements made in cases such as HTF Developers (Pty) Limited:

'NEMA is a legislative measure contemplated by section 24(b) of the Constitution. Section 2 of NEMA sets out a series of principles that give effect to the understanding that "the environment is a composite right, which includes social, economic and cultural considerations in order to ultimately result in a balanced environment." The composite nature of this right is captured in the principle that [d]evelopment must be socially, environmentally and economically sustainable. ${ }^{59}$

This passage ostensibly endorsed a crucial role of ordinary legislation in giving effect and hence specifying the protection available under section 24. However, it is not clear that this interpretation of the judgment necessarily follows. One may conclude that the specific reference to section 24 (b) is crucial, as it renders it doubtful whether the ZACC intended to state anything of relevance with respect to section 24 (a). On its face, the passage appears to apply only to the express legislative duty under section 24 (b) and cannot without further argument be applied to section 24 (a). Earlier cases also support this more limited interpretation, although the ZACC has not consistently distinguished between section 24 (a) and (b). For instance, in the earlier case of Fuel Retailers, the ZACC referred to NEMA expressly as a 'legislative measure contemplated by section 24 (b) of the Constitution.', ${ }^{60}$ as opposed to covering the entire provision.

Critics might respond that section 24 must be viewed as a composite right, ${ }^{61}$ and argue that there is no clear separation between section 24 (a) and (b) in the case law of the ZACC. This is

\footnotetext{
${ }^{58}$ Eric C. Christiansen, 'Empowerment, Fairness, Integration: South African Answers to the Question of Constitutional Environmental Rights', 254.

${ }^{59}$ HTF Developers [2007] ZACC 25 at [24], footnotes omitted.

${ }^{60}$ Ibid at [24].

${ }^{61}$ Eric C. Christiansen, 'Empowerment, Fairness, Integration: South African Answers to the Question of Constitutional Environmental Rights', 271.
} 
an important point, because if section 24 is not a composite right, then the express instruction to create instruments of ordinary legislation may well not apply to section 24 (a). Alternatively, if section 24 is a composite right then the legislative instruction would apply to both provisions. This assertion has some basis in the references to ordinary legislation, namely section 2 of NEMA, made in HTF Developers (Pty) Limited, ${ }^{62}$ and a further reference in the context of section 1 ECA in the case of BP Southern Africa. ${ }^{63}$ In these decisions, the ZACC ostensibly based its reasoning on the goals and principles set out in those provisions of ordinary legislation, notably the aim stated in these instruments to 'give effect' to the constitutional environmental right under section 24. However, as it is precisely the constitutional relevance of provisions contained in ordinary legislation that is in question, reference to these provisions has little persuasive force. None of this of course prevents ordinary legislation from making reasonable clarifications and specifications, especially where constitutional provisions expressly call for legislation to give effect to constitutional rights.

However, courts have a crucial role in overseeing this process. They are required to articulate underlying constitutional principles that arise from section 24 , clarify to what extent legislative provisions are constitutionally permissible specifications of these constitutional principles and finally interpret the legislation in a manner consistent with the constitutional provision, especially when applied to specific cases. This becomes clearer when one considers the express wording of constitutional rights where ordinary legislation takes a pivotal role in giving effect to the right. ${ }^{64}$ For instance, both sections 32 and 33 of the Constitution contain an express provision, which states that 'national legislation must be enacted to give effect to this right.' It is debateable whether the absence of a similar provision from section 24 of the Constitution is relevant. As Kate O'Regan has pointed out, the text matters to constitutional interpretation, and is central, albeit not necessarily decisive to the outcome of cases. ${ }^{65}$ Even without going so far as asserting a categorical difference between section 32 and section 24, it would at least appear that section 24 has some normative content that is currently not sufficiently articulated.

Regardless of the precise role of ordinary legislation, all rights should be given normatively enforceable content through courts. This flows directly from section 39 (2) of the Constitution. The provision states that ' $[\mathrm{w}]$ hen interpreting any legislation, and when developing the common law or customary law, every court, tribunal or forum must promote the spirit, purport and

\footnotetext{
${ }^{62}$ HTF Developers [2007] ZACC 25 at [24].

${ }^{63}$ BP Southern Africa [2004] ZAGPHC 18 at [p. 26].

${ }^{64}$ Heinz Klug, The Constitution of South Africa - A contextual analysis (Hart 2010), p. 115-6.

${ }^{65}$ Kate O'Regan, 'Text Matters: Some Reflections on the Forging of a New Constitutional Jurisprudence in South Aftica' (2012) 75 Modern Law Review 1, 10-1.
} 
objects of the Bill of Rights. ${ }^{96}$ Therefore, ordinary legislation cannot alone substantially define the protection available under constitutional rights. At the very least, courts appear to have a duty to develop the normative content of constitutional rights to ensure the supremacy of the Constitution over ordinary legislation. ${ }^{67}$ In the absence of a clear content of section 24 of the Constitution would be left normatively impoverished, uncertain, and its content might over time become virtually synonymous with ordinary legislation. In effect, ordinary legislation could thus by default define the scope of the constitutional rights, limiting the latter as a guide for the interpretation of legislation and the common law. ${ }^{68}$

Finally, a normatively impoverished understanding of section 24 of the Constitution makes it difficult, perhaps even practically impossible for applicants to challenge the constitutionality of ordinary legislation. This bears the risk of entrenching established regulatory practices and insulating them from judicial review. Applicants would often, perhaps in time inevitably, fail the high standard of demonstrating the unconstitutionality of ordinary legislation, and hence in effect be limited to claim those protections afforded by ordinary legislation. The fact that regulatory decisions are based on practically unimpeachable legislation would render it all the more difficult to effectively challenge administrative action. All but the most egregious shortcomings might be permissible and permit substantial environmental issues to remain unaddressed. This might include those risks arising from a lack of consistent updates on the basis of fresh scientific evidence, and an unwillingness to recognize emerging threats or reform enforcement proceedings.

Some commentators therefore rightly reject a strong role for ordinary legislation in defining the protections afforded by section 24 (a). They argue that in light of the primacy of the Constitution over ordinary legislation, it would be improper for a constitutional right to require such legislation in order to take effect, and that section 24 (a) must be interpreted independently. ${ }^{69}$ Instead, the relationship between constitutional rights and ordinary legislation is rightly seen as one of mutual reinforcement and support. ${ }^{70}$

\footnotetext{
${ }^{66}$ Section 39 (2), Constitution of the Republic of South Africa, 1996.

${ }^{67}$ Carmichele v Minister of Safety and Security [2001] ZACC 22 at [33-34]; Heinz Klug, The Constitution of South Africa - A contextual analysis, p. 126.

${ }^{68}$ On the problems that this practice of 'constitutional avoidance' by the US Supreme Court causes, see Neal Kumar Katyal and Thomas P Schmidt, 'Active Avoidance: The Modern Supreme Court and Legal Change' (2014) 128 Harv L Rev 2109, 2165.

${ }^{69}$ Louis J Kotzé, 'The judiciary, the environmental right and the quest for sustainability in South Africa: A critical reflection', 309-10.

${ }^{70}$ Ibid, 309-10; more cautious: Lourens Du Plessis, 'Subsidiarity: What's in the Name for Constitutional Interpretation and Adjudication', 225-7.
} 


\section{Principle of constitutional subsidiarity}

The principle of constitutional subsidiarity is crucial to understanding South African Constitutional Law. ${ }^{71}$ The modern principled was articulated in the case of South African National Defence Union, ${ }^{72}$ and defined in Mazibuko as follows:

'(...) where legislation has been enacted to give effect to a right, a litigant should rely on that legislation in order to give effect to the right or alternatively challenge the legislation as being inconsistent with the Constitution.' ${ }^{73}$

The principle hence requires an applicant 'to rely on legislation when enforcing a constitutional right rather than circumventing the legislation in favour of direct application of a constitutional provision. ${ }^{74}$ The principle thus ideally provides a principled basis for determining when a constitutional right applies directly to a case, or whether it instead finds expression in legislation designed to give effect to the constitutional right. ${ }^{75}$ The principle was more recently confirmed in the landmark decision in My Vote Counts. ${ }^{76}$ The case involved a constitutional claim from a non-profit organization seeking disclosure of information regarding private funding of political parties. The issue was whether the constitution afforded such a right, and whether the applicant was required, under the principle of constitutional subsidiarity to first rely on the statutory provisions of the Promotion of Access to Information Act (PAIA). ${ }^{77}$ The respondent argued that Parliament had created a right to access such information in the Act, and that even in the alternative, it would be incumbent on the applicant to challenge the constitutionality of PAIA before relying on constitutional rights directly. ${ }^{78}$ The ZACC confirmed the principle and stated that '[o]nce legislation to fulfil a constitutional right exists, the Constitution's embodiment of that right is no longer the prime mechanism for its enforcement. ${ }^{79}$ Crucially, the ZACC applies this principle more generally to any 'legislation Parliament adopts with the clear design of codifying a right afforded by the Bill of Rights', ${ }^{80}$ and to those provisions of the Bill of Rights

\footnotetext{
${ }^{71}$ The general existence of this principle is settled case law, see Member of the Executive Council for Development Planning and Local Government, Gauteng v Democratic Party and Others [1998] ZACC 9; 1998 (4) SA 1157 at [62]; My Vote Counts [2015] ZACC 31 at [54]; on the principle in general, see Lourens Du Plessis, 'Subsidiarity: What's in the Name for Constitutional Interpretation and Adjudication'.

${ }^{72}$ South African National Defence Union v Minister of Defence and others [2007] ZACC 10.

${ }^{73}$ Mazibuko and Others $v$ City of Johannesburg and Others [2009] ZACC 28 at [73].

${ }^{74}$ Melanie Murcott and Werner Van der Westhuizen, 'The Ebb and Flow of the Application of the Principle of Subsidiarity-Critical Reflections on Motau and My Vote Counts' (2015) 7 Const Ct Rev 43, 47.

75 Ibid, 62.

${ }^{76}$ My Vote Counts [2015] ZACC 31.

${ }^{77}$ Promotion of Access to Information Act 2 of 2000, as amended 22 January 2014.

${ }^{78}$ My Vote Counts [2015] ZACC 31 at [45].

${ }^{79}$ Ibid at [53].

${ }^{80}$ Ibid at [55]; National Education Health \& Allied Workers Union (NEHAWU) v University of Cape Town and Others [2002] ZACC 27; 2003 (2) BCLR 154 at [14]; South African National Defence Union v Minister of Defence and Others [2007] ZACC 10; 2007 (5) SA 400 at [52]
} 
that specifically require the enactment of legislation, such as section 9 (4), 25 (9), 33 (3) and 32 (3) of the Constitution. ${ }^{81}$ This appears to suggest that legislation enacted for the purposes of codifying any right will in principle lead to the application of the principle of subsidiarity, motivated by a desire to avoid the development of parallel systems of law. ${ }^{82}$

The ZACC considered applying the principle in the environmentally themed case of Mazibuko. ${ }^{83}$ The case concerned a pilot scheme run by the City of Johannesburg to address water loss and outstanding payments for water services in Soweto: it involved inter alia, the installation of pre-paid meters which were designed to ensure payment once households had exceeded their six thousand liters per month water allowance. The applicants challenged this allowance and the lawfulness of the prepaid meters on the basis of section 27 (1) (b) (Right to Access to Water) of the Constitution.

The ZACC left open the question whether the principle of subsidiarity precluded scrutiny of the reasonableness of this decision, because in any case the legislation in question was found to not comprehensively give effect to the constitutional right. Therefore, the constitutional provisions informed crucial aspects of the judgment and the Court fleshed out their normative content: it qualified section 27 (1) (b) as a positive obligation on the government to take reasonable legislative and other measures to progressively realize the right to access to water. ${ }^{84}$ Hence, the legal question centred on whether the water allowance of six thousand litres per month was reasonable. Ultimately, the ZACC declined to state what constituted 'sufficient water', as it felt this was a matter for policymakers. As the City of Johannesburg was in compliance with national regulations, and committed to continuously review its allowance policy, the ZACC judged the policy was reasonable. ${ }^{85}$ The pre-paid meters were deemed to have sufficient grounds in national legislation and local by-laws, and were seen as neither unfair nor discriminatory. ${ }^{86}$

This ruling suggests that the general applicability of the principle of constitutional subsidiarity across the Bill of Rights is possible and laudably teases out some of the normative claims of the underlying constitutional provisions. However, in line with some earlier rulings, the ZACC

\footnotetext{
${ }^{81}$ My Vote Counts [2015] ZACC 31 at [57]; Minister of Health and Another v New Clicks South Africa (Pty) Ltd and Others [2005] ZACC 14; 2006 (2) SA 311 (CC) at [96] and [437].

${ }^{82}$ My Vote Counts [2015] ZACC 31 at [63]; Melanie Murcott and Werner Van der Westhuizen, 'The Ebb and Flow of the Application of the Principle of Subsidiarity-Critical Reflections on Motau and My Vote Counts', 62.

${ }^{83}$ Mazibuko and Others v City of Johannesburg and Others [2009] ZACC 28.

${ }^{84} \mathrm{Ibid}$, at [94].

${ }^{85}$ Ibid, at [97] and [102].

${ }^{86} \mathrm{Ibid}$, at [124] and [158].
} 
formulated limitations on the general applicability of the subsidiarity principle. ${ }^{87}$ Although the conditions for application were formulated by the minority opinion in My Vote Counts, ${ }^{88}$ the majority opinion expressly endorsed the historical characterisation and the conditions for the application of the principle of constitutional subsidiarity. ${ }^{89}$ The majority took issue merely with the minority opinion that the validity of PAIA was not in question and that the applicants had hence not sought to circumvent the statutory provision through a constitutional challenge.

Hence, the ZACC was broadly in agreement with respect to conditions of application of the principle of subsidiarity as formulated by Cameron $\mathrm{J}$ for the minority. The ZACC affirms that the principle of constitutional subsidiarity is generally applicable where legislation exists that seeks to give effect to provisions of the Bill of Rights, and primarily, but not invariably, applies the principle when the legislation is enacted pursuant on an express constitutional requirement. Under these circumstances, applicants must generally invoke and rely on the legislation giving effect to the right, as opposed to constitutional right itself. These conditions further appear consistent with the previous ruling in Mazibuko.

This does not, of course, preclude two types of further challenges based directly on a constitutional right: (1) a challenge against the constitutionality of the legislation giving effect to the constitutional right; and (2) an action challenging the legislation on the basis that it has in fact not given effect to the right to the extent that is constitutionally required. ${ }^{90}$ The minority in My Vote Counts and some scholars have argued that the principle of subsidiarity is not applicable at all where legislation does not give effect to a constitutional right to the extent that is constitutionally required. This would ultimately produce largely similar results as the majority view, but would give the legislature a strong and perhaps undesirable role in determining the effective boundaries of constitutional provisions. ${ }^{91}$

\footnotetext{
${ }^{87}$ Zantsi v Council of State, Ciskei and Others [1995] ZACC 9 at [4]; Pharmaceutical Manufacturers Association of South Africa and Another: In re Ex Parte President of the Republic of South Africa and Others [2000] ZACC 1 at [33] [rejecting the notion that the review of administrative action remained determined by common law, as opposed to the Constitution]; Harksen $v$ Lane NO and Others [1997] ZACC 12 at [26] [rejecting the need to exhaust non-constitutional remedies before claiming constitutional remedies].

${ }^{88}$ My Vote Counts [2015] ZACC 31 at [67-69].

${ }^{89}$ Ibid at [121-122].

${ }^{90}$ Ibid at [155].

${ }^{91}$ Melanie Murcott and Werner Van der Westhuizen, 'The Ebb and Flow of the Application of the Principle of Subsidiarity-Critical Reflections on Motau and My Vote Counts', 63-4; Karl Klare, 'Legal Subsidiarity \& Constitutional Rights: A Reply to AJ van der Walt' (2008) 1 Const Ct Rev 129, 143.
} 


\section{Implications for section 24}

For the purposes of section 24 of the Constitution, there are a number of problems that render it difficult to draw any firm conclusions from the precedents discussed above.

First, as mentioned above, the ZACC considered, but ultimately did not definitively state whether the principle of subsidiarity precluded a review of the reasonableness of the water policy in Mazibuko on constitutional as opposed to legislative grounds. It followed the position of the previous rulings in the High Court and Supreme Court of Appeal, which both held that the legislation in question was never intended to comprehensively address or give effect to section 27 (1) (b), and hence open to constitutional scrutiny beyond compliance with the legislative framework. However, the ZACC expressed doubts as to whether mere compliance with legislation designed to give effect to a right is sufficient to demonstrate that an administrative decision was reasonable. ${ }^{92}$

Second, the general applicability of the principle of constitutional subsidiarity to the Bill of Rights appears well established in constitutional jurisprudence. However, it is worth pointing out that the scope of its application is not yet clear with respect to section 24 of the Constitution. Some inferences may be drawn from the application of the principle to other rights in ZACC judgments, but most of the rights considered contain an express provision requiring legislative action and occurred the context of specific legislative instruments. ${ }^{93}$ Whether it ultimately makes a difference to the application of the principle of subsidiarity whether a constitutional right envisions ordinary legislation is largely unclear. ${ }^{94}$

Even if one were to assume that the principle of subsidiarity applies to section 24 in the same manner as with other provisions, this would necessitate a further argument that the conditions outlined above are met within the context of the specific case and environmental legislation in question. One would have to demonstrate that the environmental legislation adopted seeks to comprehensively describe and give effect to the right contained in section 24. Even with broad

\footnotetext{
${ }^{92}$ Mazibuko and Others $v$ City of Johannesburg and Others [2009] ZACC 28 at [74].

${ }^{93}$ See for instance, Bato Star Fishing (Pty) Ltd v Minister of Environmental Affairs and Tourism and Others [2004] ZACC 15 at [25-26] [ordinary legislation giving effect to Section 33 (administrative justice) of the Constitution]; MEC for Education Kwazulu-Natal and others v Pillay [2007] ZACC 21 at [40] [ordinary legislation giving effect to Section 9 (Equality) of the Constitution]; South African National Defence Union $v$ Minister of Defence and others [2007] ZACC 10 at [51-52] [ordinary legislation to give effect to labour rights protected in Section 23 of the Constitution]; PFE International Inc (BVI) and Others $v$ Industrial Development Corporation of South Africa Ltd [2012] ZACC 21 at [4] [ordinary legislation giving effect to Section 32 of the Constitution (access to information)]; see also Melanie Murcott and Werner Van der Westhuizen, 'The Ebb and Flow of the Application of the Principle of Subsidiarity-Critical Reflections on Motau and My Vote Counts', 65. ${ }^{94}$ Michael Kidd, 'Environment', p. 528.
} 
legislation such as NEMA there is likely to be sufficient scope for unforeseen applications scenarios and legislative blind spots. In any case, it is difficult to ascertain whether ordinary legislation gives effect to section 24 in the absence of a clear notion of the right independent from ordinary legislation: environmental issues are by their nature a dynamic and rapidly evolving field.

Finally, regardless of how the principle of subsidiarity operates with respect to a specific constitutional provision, a clear and independent idea of the normative content is crucial. Otherwise it would be impossible for the ZACC to distinguish between a constitutionally permissible clarification of constitutional provisions through ordinary legislation, and highly problematic attempts to alter the protections offered by the Constitution through a process that does not meet the requirements for formal constitutional amendment. ${ }^{95}$ Naturally this does not preclude a strong role for ordinary legislation in specifying, in a constitutionally permissible manner, the content of the right in practice. This is especially true where a provision already foresees a strong role for ordinary legislation in giving effect to a certain right.

\section{CONCLUSION}

Legal scholarship and courts in South Africa have not yet had occasion to discuss the scope and implications of section 24 of the Constitution in much detail. There are few firm principles and its role in the constitutional order of South Africa, or the Bill of Rights more specifically, is an open question in many important respects. Several commentators have lamented the lack of engagement and pertinent case law over the years. ${ }^{96}$ Kidd and Feris have both recounted numerous examples where South African courts did not engage with section 24 of the Constitution despite clear environmental dimensions of the cases brought before them. ${ }^{97}$ Apart

\footnotetext{
${ }^{95}$ See section 74 Constitution of the Republic of South Africa, 1996.

${ }^{96}$ Environmental Law and Local Government in South Africa, p. 223; L Feris, 'Environmental rights and locus standi' in A Sachs, AR Paterson and LJ Kotzé (eds), Environmental compliance and enforcement in South Africa: legal perspectives (Juta and Company Ltd 2009); Anél Du Plessis, 'Adding Flames to the fuel: Why further constitutional adjudication is required for South Africa's Constitutional right to catch alight' (2008) 57 SAJELP 60; Loretta Feris, 'Constitutional environmental rights: An under-utilised resource', 38; Michael Kidd, 'Greening the judiciary'; James R. May and Erin Daly, Global Environmental Constitutionalism, p. 2; Louis J Kotzé and Anél du Plessis, 'Some brief observations on fifteen years of environmental rights jurisprudence in South Africa', 165.

${ }^{97}$ Michael Kidd, 'Greening the judiciary', 1; Loretta Feris, 'Constitutional environmental rights: An underutilised resource', 38 .
} 
from general definitional uncertainties surrounding section 24, there are three key unanswered doctrinal question with potentially far-reaching implications.

First, it is unclear if section 24 encompasses one individual right (paragraph a) and a separate positive obligation (paragraph b). If that is the case, then it renders a straight-forward application of the principle of subsidiarity along the lines of other constitutional provisions such as section 32 and section 33 less likely. This is because only section 24 (b) contains the express instruction to create instruments of ordinary legislation that give effect to the right, and the principle of subsidiarity may well work differently with respect to section 24 (a) where this instruction is absent. This reading is supported by the cautious approach of the ZACC in Mazibuko, where it ultimately did not clarify whether the principle of subsidiarity precluded scrutiny of the reasonableness of the water scheme. Alternatively, if section 24 is a composite right as suggested by other commentators, then the case for the ordinary application of the principle of subsidiarity is stronger because then the instruction to legislate applies equally to both subsections. The case of HTF Developers offers some tentative hints in that direction.

Second, it is unclear to what extent the individual right contained in section 24 absolutely requires legislative instruments to 'give effect' to the right. Perhaps the best reading of the case law and scholarship is that while legislation is not strictly necessary, it may of course nonetheless inform the normative content of section 24 . In this way, legislation such as NEMA may take on an otherwise unproblematic quasi-constitutional status and thus represent a specific expression of the rights protected in section 24. However, even then, the normative content of constitutional provisions must be specified for reasons that chiefly revolve around the status and function of the constitution as a standard of review for administrative action and legislation.

Finally, it is unclear how the principle of subsidiarity applies to on section 24 of the Constitution. Even assuming that the principle applies in essentially the same way as to other constitutional provisions, this render clarifications and fleshing out of the normative content all the more crucial. One cannot reasonably determine whether ordinary legislation reflects and gives effect to a constitutional right, if one has no clear notion of the latter's content. It is hardly surprising, nor necessarily a cause for concern when constitutional provisions and ordinary legislation form complex interactions in constitutional theory and especially when applied to a specific case in constitutional practice. This is true even of the interactions between different provisions within constitutions, for instance between constitutional preambles and the 
subsequent norms, ${ }^{98}$ and with respect to ordinary legislation wherever the Constitution itself envisions clarification of constitutional provisions through statutes. ${ }^{99}$

However at an empirical level it appears that environmental issues before South African courts are primarily litigated on the basis of ordinary legislation: constitutional rights are only invoked infrequently, and generally not afforded much attention in judgments. As it stands, the practical impact of section 24 appears limited in the South African constitutional order. Given the greater prominence and awareness of environmental threats to human health and well-being this incomplete doctrinal position ought to be clarified as a matter of urgency. Otherwise, the constitutional provision runs the risk of being rendered redundant in the face of supposedly comprehensive instruments of ordinary legislation. Questions surrounding the NEMA already account for the lion's share of environmental cases in South Africa, and a normatively impoverished section 24 is scarcely a suitable standard of review for administrative action or legislation.

\footnotetext{
${ }^{98}$ Peter Häberle, 'Präambeln im Text und Kontext von Verfassungen' in J Listl and H Schambeck (eds), Demokratie in Anfechtung und Bewährung - Festschrift für Johannes Broermann (Duncker \& Humblot 1982); Stefan Theil, 'Three insights from Peter Häberle's "Preambles in the text and context of constitutions"' (UK Constitutional Law Blog, 25.03.2015) <ukconstitutionallaw.org/2015/03/25/stefan-theil-three-insights-frompeter-haberles-preambles-in-the-text-and-context-of-constitutions $>$ accessed 19.07.2015.

${ }^{99}$ Examples are abound in constitutions, see for instance Article 14 of the Basic Law for the Federal Republic of Germany (adopted 8 May 1949, in force 23 May 1949, as last amended 23 December 2014) (GG) and section 32 of the Constitution of the Republic of South Africa, 1996, which both make such provisions.
} 